\title{
PTPL1 and PKC $\delta$ contribute to proapoptotic signalling in prostate cancer cells
}

\author{
C Castilla ${ }^{1}$, D Chinchón ${ }^{2}$, R Medina ${ }^{3}$, FJ Torrubia ${ }^{3}$, MA Japón ${ }^{1,2,4}$ and C Sáez ${ }^{\star, 1,4}$
}

PTPL1 is a non-receptor protein tyrosine phosphatase involved in apoptosis regulation, although controversial findings have been reported in different cancer types. We report here a proapoptotic role for PTPL1 in PC3 and LNCaP prostate cancer cells, as its absence induces apoptosis resistance upon treatment with different drugs. In PC3 cells, PTPL1 silencing by small interfering RNA influences the expression levels of $\mathrm{Bcl}-\mathrm{xL}$ and $\mathrm{Mcl}-1_{\mathrm{s}}$ proteins as well as final events in the apoptotic process such as activation of caspases and caspase-mediated cleavage of proteins like Mcl-1 or poly (ADP-ribose) polymerase. We have identified PKC $\delta$ as an intermediary of PTPL1-mediated apoptotic signalling and that phosphorylation status of NF- $\kappa \mathrm{B}$ and $I \kappa \mathrm{B} \alpha$ is influenced by PTPL1 and PKC $\delta$. Furthermore, the loss of PTPL1 and PKC $\delta$ expression in poorly differentiated, more aggressive human prostate cancers also indicate that their absence could be related to apoptosis resistance and tumour progression.

Cell Death and Disease (2013) 4, e576; doi:10.1038/cddis.2013.90; published online 4 April 2013

Subject Category: Cancer

Prostate cancer is one of the most frequently diagnosed cancers. Castration therapy remains the most widely used treatment for locally advanced prostate cancer and although initially effective, after months to few years this therapy fails, leading to a lethal hormone-refractory disease. ${ }^{1}$ Unfortunately, the mechanisms underlying resistance of castrationresistant prostate cancer cells to chemotherapy-mediated apoptosis are still unknown. Two main pathways of apoptosis in mammalian cells are the death receptor and the mitochondrial pathways. In type I cells, engagement of Fas receptor either by Fas ligand or by antibody cross-linking induces the formation of a death-inducing signalling complex (DISC) that leads to activation of caspase 8. The activation of downstream caspases by the DISC is sufficient for the execution of Fasinduced apoptosis. ${ }^{2}$ In type II cells, such as PC3 prostate cancer cells, ${ }^{3}$ there is reduced DISC formation and $\mathrm{Bcl}-2$ or $\mathrm{BCl}-\mathrm{XL}$ protect against Fas-mediated apoptosis. ${ }^{2}$ Thus, depending on the cell type, Fas-mediated apoptosis can be dependent or independent on the mitochondrial pathway.

Protein tyrosine phosphatase L1 (PTPL1, also known as PTPN13, FAP-1, PTP-BAS or hPTP1E) is a non-receptor protein tyrosine phosphatase whose role in apoptosis is a matter of debate. Several groups have addressed an antiapoptotic role for PTPL1 in different cell lines, mainly by inhibition of Fas-mediated apoptosis, while others have demonstrated a proapoptotic function. ${ }^{4}$ Studies in HeLa, HEK293 cells, and breast cancer cells showed that PTPL1 dephosphorylates IRS-1 and induces apoptosis at least by inhibition of the IGF-IR/IRS-1/PI3K/Akt pathway. ${ }^{5,6}$ In SW480 colon cancer cells, PTPL1 overexpression increases susceptibility to Fas-mediated apoptosis. ${ }^{7}$ Data regarding PTPL1 function in prostate cancer cells are still lacking. Phenylethyl isothiocyanate (PEITC) is present in cruciferous vegetables ${ }^{8}$ and several studies have indicated that it can inhibit prostate cancer cell growth in vitro and in vivo, and induce apoptosis. ${ }^{9-11}$ PEITC-induced apoptosis has been correlated with changes in the protein levels of $\mathrm{Bcl}-2$ family proteins in PC3 and TRAMPderived cells. ${ }^{9,11,12}$ Especially, ectopic expression of $\mathrm{Bcl}-\mathrm{xL}$ in PC3 cells has been shown to confer partial protection against PEITC-induced apoptosis. ${ }^{11}$ It has also been proposed that PEITC inhibits $I_{\kappa} \mathrm{B} \alpha$ phosphorylation and its subsequent degradation and the nuclear translocation of the p65 subunit of NF- $\kappa$ B in PC3 cells stably transfected with an NF- $\kappa B$-luciferase reporter construct. ${ }^{13}$

Thus, we sought to investigate in prostate cancer cells the apoptotic effect of PEITC and anti-Fas antibody either alone or in combination, the influence of PTPL1 in the apoptosis induced by these stimuli and the signalling pathways involved in the process.

\section{Results}

PEITC sensitizes PC3 cells to anti-Fas induced apoptosis. As previously established, ${ }^{10-12}$ PC3 cells are sensitive to

\footnotetext{
${ }^{1}$ Instituto de Biomedicina de Sevilla (IBiS), Hospital Universitario Virgen del Rocío/CSIC/Universidad de Sevilla, Seville 41013, Spain; ${ }^{2}$ Department of Pathology, Hospital Universitario Virgen del Rocío, Seville 41013, Spain and ${ }^{3}$ Department of Urology, Hospital Universitario Virgen del Rocío, Seville 41013, Spain

${ }^{*}$ Corresponding author: C Sáez, Instituto de Biomedicina de Sevilla (IBiS), Hospital Universitario Virgen del Rocío/CSIC/Universidad de Sevilla, Av. Manuel Siurot s/n, 41013 Seville, Spain. Tel: +34 955013 028; Fax: +34 9555013 029; E-mail: csaez@ cica.es

${ }^{4}$ These authors contributed equally to this work.

Keywords: prostate cancer; apoptosis; PTPL1; PKC $\delta$

Abbreviations: DISC, death-inducing signalling complex; CASP, caspase; DMSO, dimethyl sulfoxide; EDTA, ethylenediaminetetraacetic acid; FITC, fluorescein isothiocyanate; HEPES, 4-(2-hydroxyethyl)-1-piperazineethanesulfonic acid; IGF-IR, insulin-like growth factor receptor type 1; IRS-1, insulin receptor substrate-1; NP-40, nonidet-P40; PARP, poly (ADP-ribose) polymerase; PBS, phosphate buffered saline; PCR, polymerase chain reaction; PEITC, phenylethyl isothiocyanate; $\mathrm{PI}$, propidium iodide; PI3K, phosphatidylinositol 3-kinase; PKC $\delta$, protein kinase C $\delta$; PTPL1, protein tyrosine phosphatase L1; RPL13A, ribosomal protein L13A; SDS-PAGE, sodium dodecyl sulfate-polyacrylamide gel electrophoresis; siRNA, small interfering RNA; TRAMP, transgenic adenocarcinoma of the mouse prostate Received 25.9.12; revised 15.2.13; accepted 19.2.13; Edited by A Stephanou
} 
PEITC-mediated apoptosis and our experiments also confirm this issue (Figure 1). Data regarding anti-Fas sensitivity of PC3 cells are more controversial, ${ }^{14-16}$ but they were relatively sensitive to anti-Fas treatment, as it produces a slight induction of apoptosis. However, when cells were pre-treated with PEITC

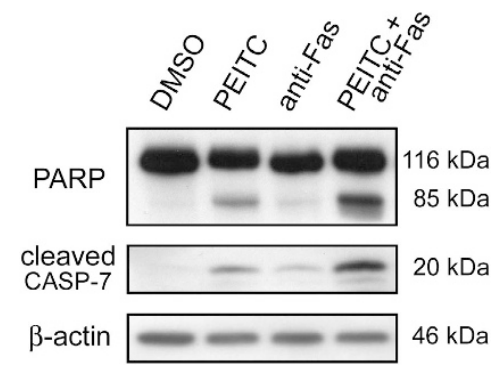

Figure 1 PEITC sensitizes PC3 cells to anti-Fas induced apoptosis. Subconfluent PC3 cells were treated with $10 \mu \mathrm{M}$ PEITC or $0.5 \mu \mathrm{g} / \mathrm{ml}$ anti-Fas for $48 \mathrm{~h}$ and with $10 \mu \mathrm{M}$ PEITC for $1 \mathrm{~h}$ plus $0.5 \mu \mathrm{g} / \mathrm{ml}$ anti-Fas for $16 \mathrm{~h}$. Apoptosis induction was measured by the appearance of the $85 \mathrm{kDa}$ and the $20 \mathrm{kDa}$ cleaved products of PARP and caspase-7 proteins, respectively. $\beta$-Actin is shown as loading control for $1 \mathrm{~h}$ and then anti-Fas antibody was added, we observed a significantly more extensive apoptosis than with either PEITC or anti-Fas alone. poly (ADP-ribose) polymerase (PARP) and caspase-7 cleavage were clearly more pronounced in PC3 cells treated with PEITC and anti-Fas in combination, followed by cells treated with PEITC alone and then by cells treated with anti-Fas alone (Figure 1). Thus, simultaneous treatment with PEITC and anti-Fas causes a more extensive apoptosis in PC3 cells than any of the drugs separately.

PTPL1 silencing abrogates apoptosis induction in PC3 cells. We sought to investigate the influence of PTPL1 expression on the sensitivity to apoptosis of PC3 cells. Figure 2 a shows knockdown of endogenous PTPL1 by small interfering RNA (siRNA), at both the mRNA and protein levels. As observed by PARP cleavage (Figure 2b), PC3 cells silenced for PTPL1 showed less sensitivity to apoptosis than siRNA control cells. The effect was seen either with PEITC or anti-Fas alone or with both drugs but again it was more striking when PEITC and anti-Fas were used in combination. Then, several proteins involved in apoptosis were examined (Figure 2c). Caspases 3, 7, and 9 were more a

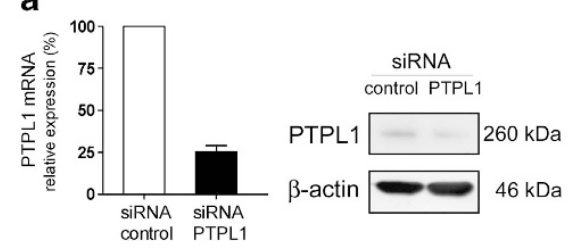

C

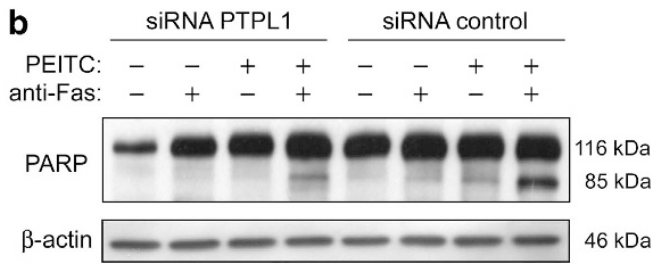

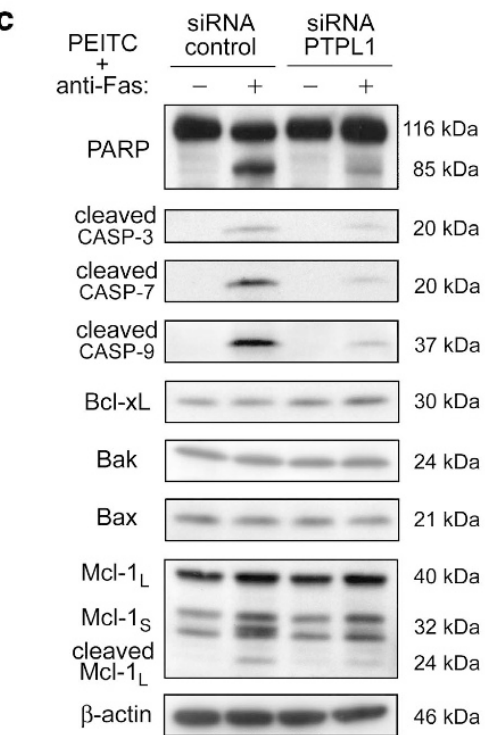

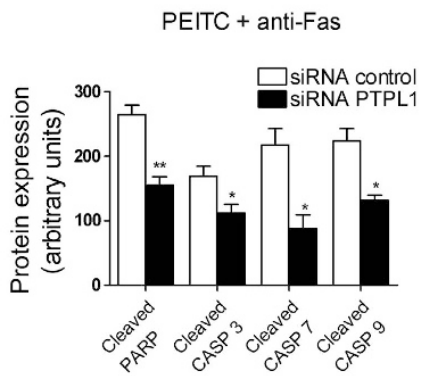

Figure 2 PTPL1 silencing promotes apoptosis resistance in PC3 cells treated with PEITC plus anti-Fas. (a) PTPL1 silencing by small interfering RNA in PC3 cells. Seventy-two hours after silencing, downregulation of PTPL1 expression was monitored by western blot and RT-PCR. The quantity of PTPL1 transcript was divided by the quantity of RPL13A to obtain a normalized value. Data represent the mean of three experiments \pm S.E.M. (b) PC3 cells were silenced with PTPL1 siRNA or with a nontargeting control siRNA and then treated with DMSO, $10 \mu \mathrm{M}$ PEITC, or $0.5 \mu \mathrm{g} / \mathrm{ml}$ anti-Fas for $48 \mathrm{~h}$ and with $10 \mu \mathrm{M}$ PEITC for $1 \mathrm{~h}$ plus $0.5 \mu \mathrm{g} / \mathrm{ml}$ anti-Fas for $16 \mathrm{~h}$. Apoptosis was assessed by western blot of PARP. (c) PC3 cells were silenced with PTPL1 siRNA or with a non-targeting control siRNA and treated with DMSO or $10 \mu \mathrm{M}$ PEITC for $1 \mathrm{~h}$ plus $0.5 \mu \mathrm{g} / \mathrm{ml}$ anti-Fas for $16 \mathrm{~h}$. Western blot analyses of PARP, active caspases 3,7 , and 9, Bcl-xL, Bak, Bax, and Mcl-1 proteins are shown. $\beta$-Actin is used as loading control. Histogram in (c) shows the densitometric analysis of cleaved PARP and active caspases 3, 7, and 9 in PC3 cells silenced with a non-targeting control siRNA or with PTPL1 siRNA treated with $10 \mu \mathrm{M}$ PEITC for $1 \mathrm{~h}$ plus $0.5 \mu \mathrm{g} / \mathrm{ml}$ anti-Fas for $16 \mathrm{~h}$. Data are presented as mean \pm S.E.M. $(n=3) .{ }^{*} P<0.05$ and ${ }^{*} P<0.01$ from Student's t-test, comparing treated siRNA control versus treated siRNA PTPL1 PC3 cells. The experiment was performed at least three times 
active in siRNA control cells treated with PEITC and anti-Fas than in treated siRNA PTPL1 cells. Multidomain proapoptotic proteins Bax and Bak remain unchanged in the presence or absence of PTPL1; however, anti-apoptotic $\mathrm{Bcl}-\mathrm{xL}$ is increased in PC3 cells silenced for PTPL1 $(P<0.05)$. Remarkably, we observed an increase in the proapoptotic short form of $\mathrm{Mcl}-1$ ( $\left.\mathrm{Mcl}-1_{\mathrm{S}}\right)$ in siRNA control cells treated with PEITC and anti-Fas, and the appearance of the 24-kDa cleaved fragment of $\mathrm{Mcl}-1_{\mathrm{L}}$ was also more evident in this condition. All these data are in accordance with the greater sensitivity to apoptosis of PC3 cells expressing endogenous PTPL1. To test whether the protective effect of PTPL1 silencing on apoptosis also occurred with other stimuli, siRNA control and siRNA PTPL1 PC3 cells were treated with PEITC alone or paclitaxel. Cells silenced for PTPL1 were more resistant to PEITC and paclitaxel-induced apoptosis than siRNA control cells, as observed by the cleaved fragments of PARP and caspases 3, 7, and 9 (Figures $3 a$ and $\mathrm{c}$ ). Annexin $\mathrm{V}$ binding/PI assays also confirmed these data (Figures $3 b$ and $d$ ). All these data point towards a proapoptotic role for PTPL1 in PC3 cells.

Signal transduction regulated by PTPL1 involves PKC $\delta$. Following an initial screening of kinases (data not shown), we focus on protein kinase $\mathrm{C}$ delta $(\mathrm{PKC} \delta)$ and a diminished $\mathrm{PKC} \delta$ phosphorylation was detected at T505 (located within the activation loop of the kinase) in cells with endogenous PTPL1 treated with PEITC and anti-Fas, undergoing apoptosis. On the contrary, cells silenced for PTPL1 treated in the same way, with impaired apoptosis, sustained the basal level of PKC $\delta$ T505 phosphorylation. The decrease in the phosphorylation of $\mathrm{PKC} \delta$ at T505 occurs in PC3 cells expressing endogenous PTPL1 treated with PEITC and antiFas, PEITC or paclitaxel and was not primarily due to downregulation of $\mathrm{PKC} \delta$ expression (Figures $4 \mathrm{a}$ and $\mathrm{b}$ ). As reported, $\mathrm{PKC} \delta$ is a functional kinase even without T505 phosphorylation ${ }^{17,18}$ and to study more profoundly the involvement of PTPL1-dependent $\mathrm{PKC} \delta$ regulation in
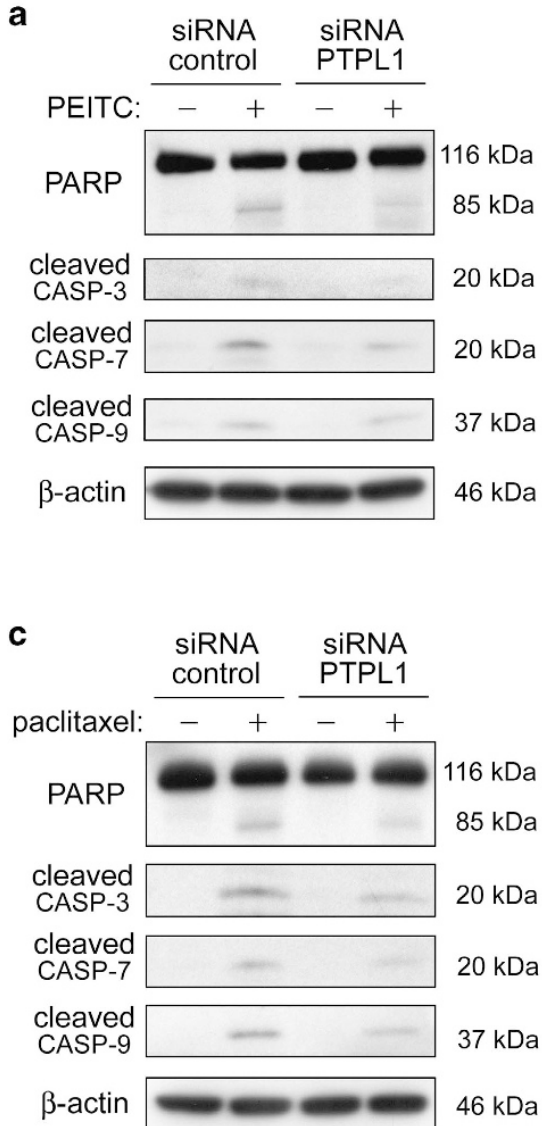

PEITC

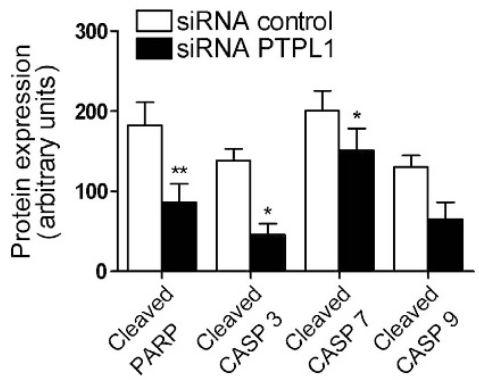

paclitaxel

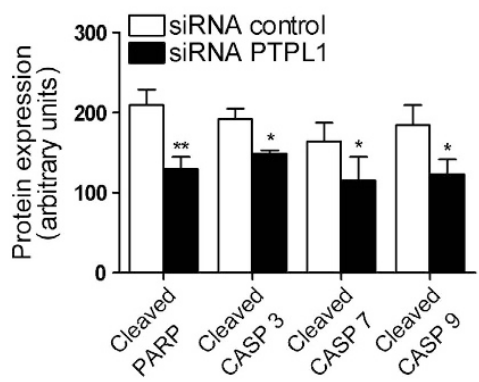

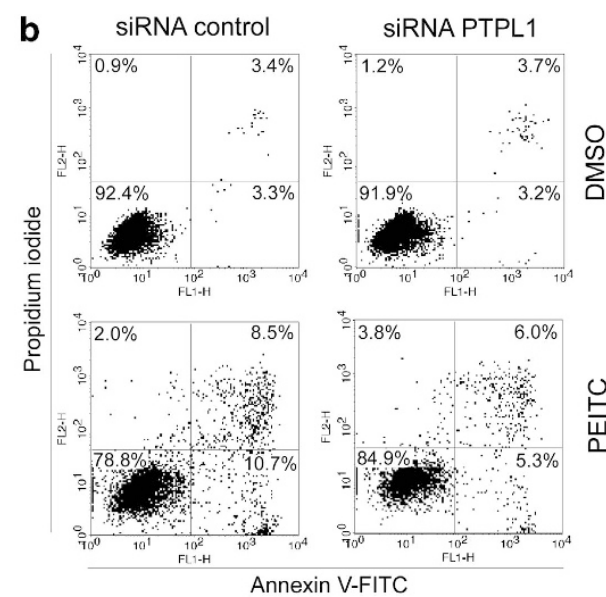

d

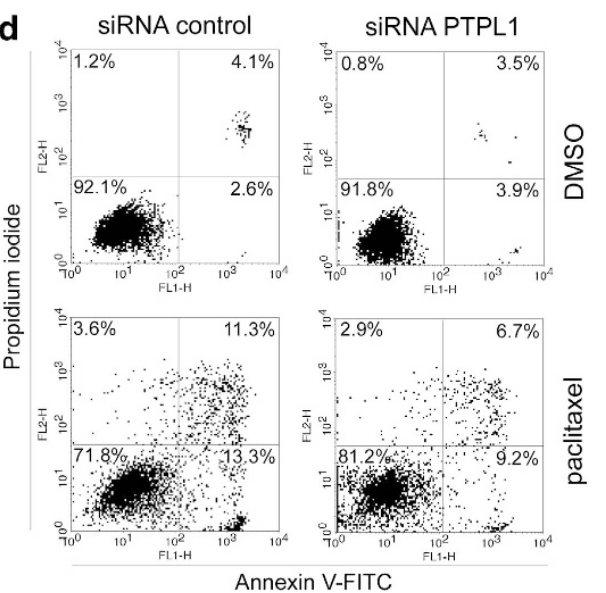

Figure 3 PTPL1 silencing also promotes apoptosis resistance in PC3 cells treated with PEITC or paclitaxel. (a and $\mathbf{b})$ PC3 cells were silenced with PTPL1 siRNA or with a non-targeting control siRNA and treated with $10 \mu \mathrm{M}$ PEITC for $48 \mathrm{~h}$. Apoptosis was assessed by western blot of PARP protein and active caspases 3,7 , and 9 (a) and by flow cytometry of annexin V and propidium iodide-labelled cells, to identify viable, early apoptotic and late apoptotic or necrotic cells (b). (c and d) PC3 cells were silenced with PTPL1 siRNA or with a non-targeting control siRNA and treated with $2.5 \mu \mathrm{M}$ paclitaxel for $48 \mathrm{~h}$. Apoptosis was assessed by western blot of PARP protein and active caspases 3,7 , and 9 (c) and by flow cytometry of annexin V and propidium iodide-labelled cells (d). $\beta$-Actin is shown as loading control in all cases. Histograms in (a) and (c) show the densitometric analysis of cleaved PARP and active caspases 3,7 , and 9 in PC3 cells silenced with a non-targeting control siRNA or with PTPL1 siRNA treated with $10 \mu \mathrm{M}$ PEITC (a) or $2.5 \mu \mathrm{M}$ paclitaxel (c) for $48 \mathrm{~h}$. Data are presented as mean \pm S.E.M. $(n=3) .{ }^{*} P<0.05$ and ${ }^{* *} P<0.01$ from Student $t$ test, comparing treated siRNA control versus treated siRNA PTPL1 PC3 cells. The experiments were performed at least three times 

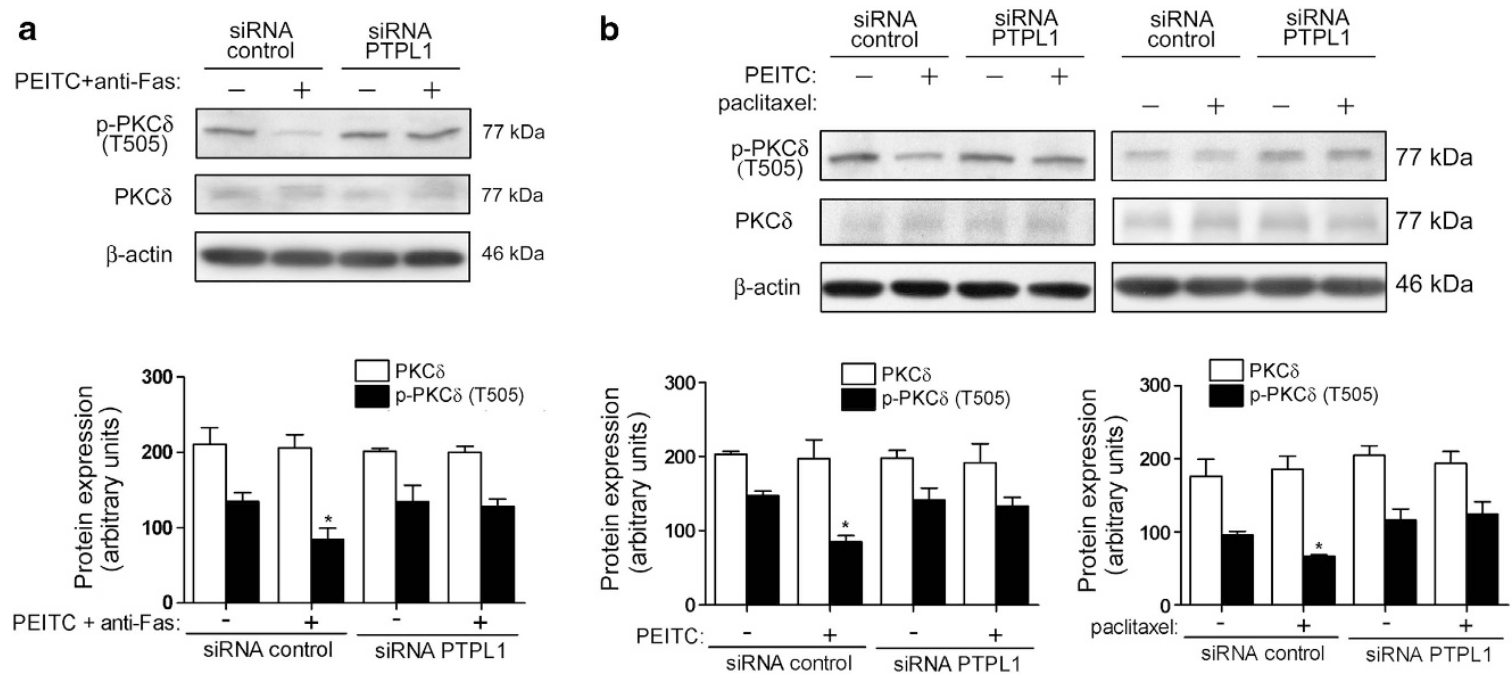

Figure 4 PTPL1 regulates PKC $\delta$ phosphorylation on T505. (a) PC3 cells were silenced with PTPL1 siRNA or with a non-targeting control siRNA and treated with $10 \mu \mathrm{M}$ PEITC for $1 \mathrm{~h}$ plus $0.5 \mu \mathrm{g} / \mathrm{ml}$ anti-Fas for $16 \mathrm{~h}$. Total PKC $\delta$ and T505 phosphorylated PKC $\delta$ were assessed by western blot. (b) PC3 cells were silenced with PTPL1 siRNA or with a non-targeting control siRNA and treated with $10 \mu \mathrm{M}$ PEITC or $2.5 \mu \mathrm{M}$ paclitaxel for $48 \mathrm{~h}$. Total PKC $\delta$ and T505 phosphorylated PKC $\delta$ were assessed by western blot. Histograms in (a) and (b) show the densitometric analysis of PKC $\delta$ and T505 phosphorylated PKC $\delta$ in PC 3 cells silenced with a non-targeting control siRNA or with PTPL1 siRNA treated as indicated. $\beta$-Actin is used to ensure equal loading. Data are presented as mean \pm S.E.M. $(n=3) .{ }^{*} P<0.05$ from Student's $t$ test, comparing T505 phosphorylated PKC $\delta$ in treated versus untretated control and PTPL1-silenced PC3 cells. The experiments were performed at least three times

apoptosis; an approach was performed using simultaneous PTPL1 and PKC $\delta$ silencing. First, flow cytometry shows that percentage of apoptotic cells was higher in PEITC and antiFas-treated siRNA control cells than in any other condition (45.2\% in treated siRNA control cells versus $26.7 \%$ in treated siRNA PKC $\delta$ cells, $17.5 \%$ in treated siRNA PTPL1 cells and $10.5 \%$ in treated siRNA PKC $\delta$ and PTPL1 cells) (Figure 5a). These data were confirmed by diminished cleavage of PARP and caspases 3,7 , and 9 in all treated siRNA conditions (Figure 5b). Thus, interestingly, $\mathrm{PKC} \delta$ siRNA, in the same way as PTPL1 silencing, induces apoptosis resistance upon treatment; moreover, simultaneous PTPL1 and PKC $\delta$ silencing, produces greater resistance to apoptosis than either PTPL1 or PKC $\delta$ silencing alone. To further confirm the apoptosis resistance obtained in siRNA $\operatorname{PKC} \delta$ cells treated with PEITC and anti-Fas, PC3 cells were silenced with PKC $\delta$ siRNA and treated with PEITC alone or paclitaxel. Annexin V binding/PI assays showed decreased apoptosis upon $\mathrm{PKC} \delta$ silencing after treatment with both drugs (Supplementary Figure S1).

It has been reported that a mutant $\mathrm{PKC} \delta$ unable to become phosphorylated in the activation loop lacks the capacity to induce NF- $\kappa$ B reporter activation, ${ }^{18}$ so the activation status of $\mathrm{NF}-\kappa \mathrm{B}$ was determined, measured by the phosphorylation of S276 of the p65 subunit, a phosphorylation known to be important for optimal transactivation activity of NF- $\kappa \mathrm{B} .{ }^{19}$ Cells silenced for $\mathrm{PKC} \delta$ or both PTPL1 and $\mathrm{PKC} \delta$ maintain, approximately, the same level of $\mathrm{NF}-\kappa \mathrm{B}$ S276 phosphorylation either in untreated or in PEITC and anti-Fas-treated cells, whereas its phosphorylation level shows a slight decrease in treated PTPL1-silenced cells and is pronouncedly diminished in treated cells expressing endogenous PTPL1 and PKC $\delta$. Total level of NF- $\kappa$ B protein remains unaffected (Figure $5 b$ ). To test whether these changes in the activation status of $\mathrm{NF}-\kappa \mathrm{B}$ after PEITC and anti-Fas treatment were accompanied by changes in the subcellular distribution of the protein, an immunofluorescence assay was performed (Supplementary Figure S2). PEITC and anti-Fas treated siRNA control cells shows cytosolic staining, whereas treated siRNA PTPL1 and siRNA $\mathrm{PKC} \delta$ cells show a redistribution of the protein from cytosol to the nucleus, according to the higher activation of $\mathrm{NF}-\kappa \mathrm{B}$ found in these conditions in relation to siRNA control cells.

Then, we focused on $\mathrm{I} \kappa \mathrm{B} \alpha$, another regulator of $\mathrm{NF}-\kappa \mathrm{B}$ activity. $\mathrm{I} \kappa \mathrm{B} \alpha$ serine phosphorylation on residues 32 and 36 results in its proteolytic degradation and NF- $\kappa$ B activation. ${ }^{20}$ Figure $5 b$ shows that $\mathrm{I}_{\kappa} \mathrm{B} \alpha$ phosphorylation on S32 and S36 presents the major decrease in PC3 cells expressing endogenous PTPL1 and PKC $\delta$ treated with PEITC and antiFas, whereas dephosphorylation is impaired in treated cells silenced for $\mathrm{PKC} \delta$, PTPL1, or both PTPL1 and PKC $\delta$. I $1 \kappa \mathrm{B} \alpha$ phosphorylation at $\mathrm{Y} 42$ also leads to $\mathrm{I} \kappa \mathrm{B} \alpha$ dissociation from $\mathrm{NF}-\kappa \mathrm{B},{ }^{20}$ so its phosphorylation level was also assessed. $\mathrm{Y} 42$ phosphorylated $\mathrm{I} \kappa \mathrm{B} \alpha$ also shows a major decrease in treated cells expressing PTPL1 and PKC $\delta$ than in any other condition tested. $I \kappa \mathrm{B} \alpha$ total level does not show noticeable changes.

Finally, Akt phosphorylation status was also addressed in this setting. There was a noticeable diminishing of Akt phosphorylation on S473 in PC3 cells silenced for PTPL1, but the treatment with PEITC and anti-Fas induced a decrease in Akt phosphorylation irrespective of the presence or absence of PTPL1 or PKC $\delta$ (Figure $5 \mathrm{~b}$ ).

PTPL1 or PKC $\delta$ overexpression enhances apoptosis induction in PC3 cells. Next, PC3 cells were transfected with a plasmid containing PTPL1 or $\mathrm{PKC} \delta$ and they were subsequently treated with PEITC and anti-Fas. Annexin V binding/PI assays showed an increase in apoptotic cells in both drug-treated PTPL1 and PKC $\delta$-transfected cells $(46.4 \%$ in treated empty vector-transfected cells versus $54.9 \%$ in 

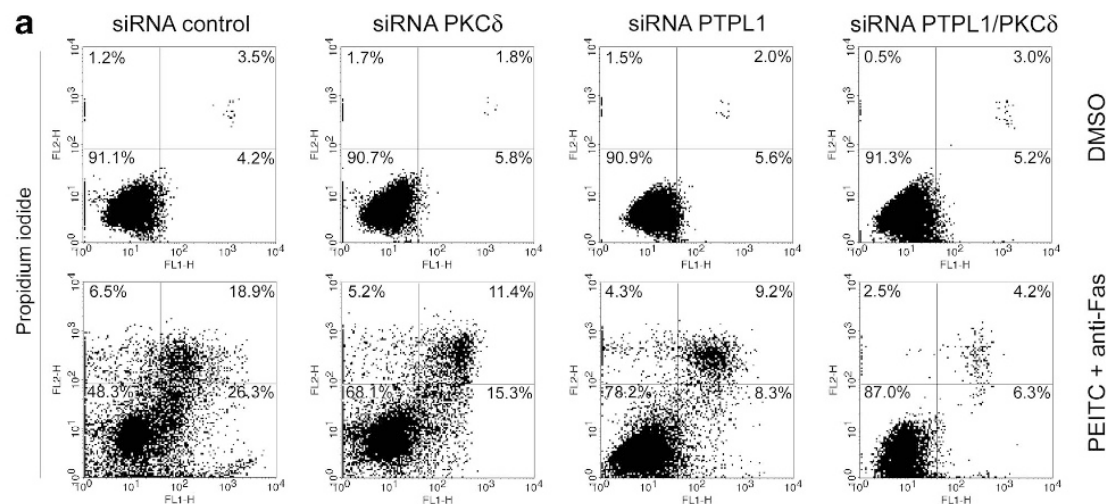

Annexin V-FITC

b

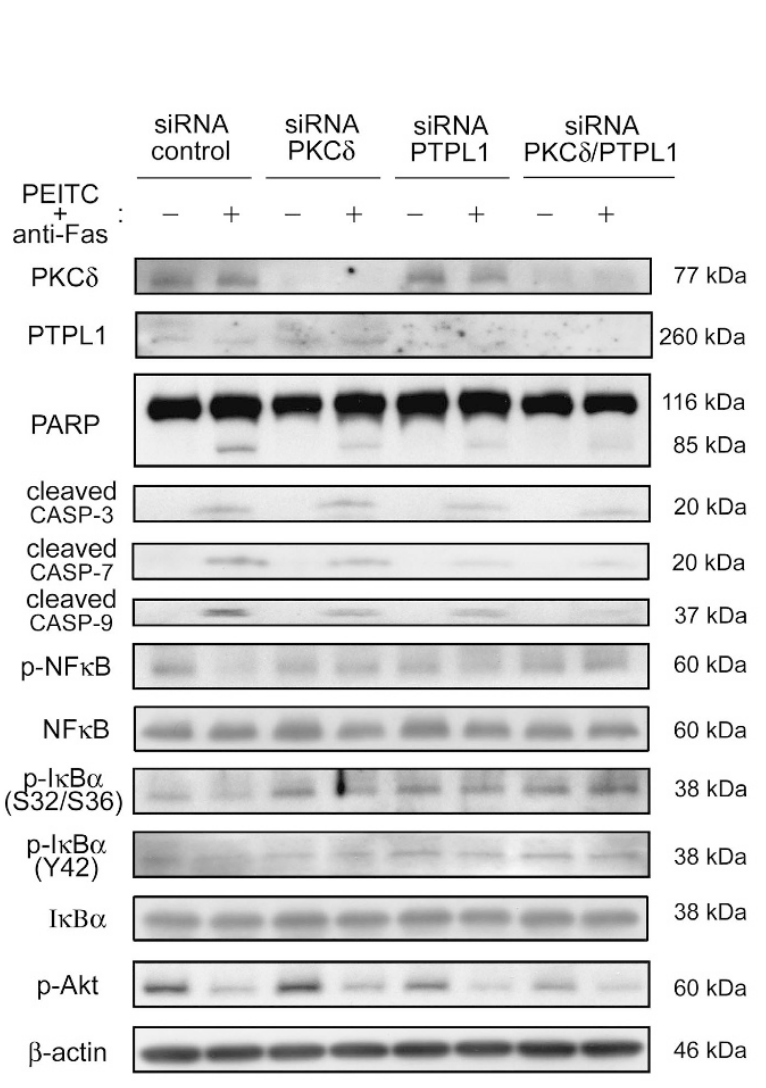

PEITC + anti-Fas

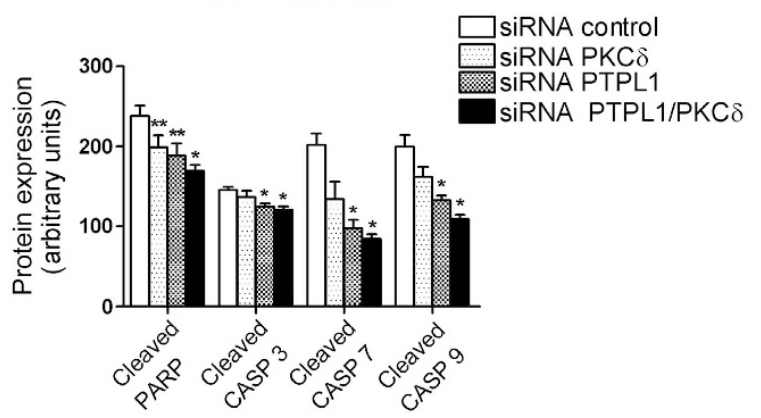

$\mathrm{p}-\mathrm{IkB} \alpha(\mathrm{S} 32 / \mathrm{S} 36)$

$\mathrm{p}-\mathrm{NF} \kappa \mathrm{B}$

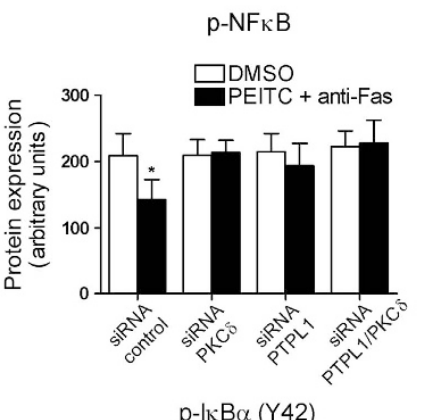

$\mathrm{p}-\mid \kappa \mathrm{B} \alpha(\mathrm{Y} 42)$

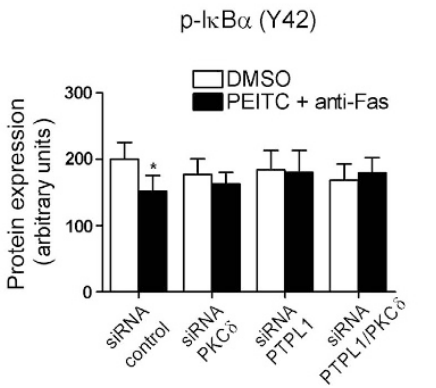

$\sum_{0}^{\infty}$

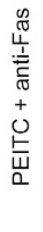

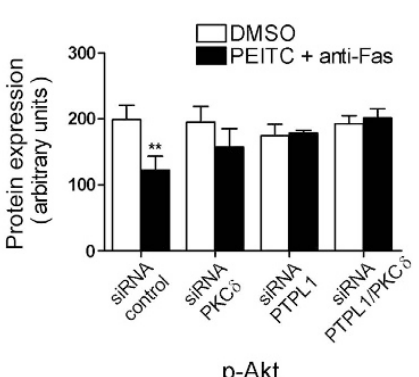

p-Akt

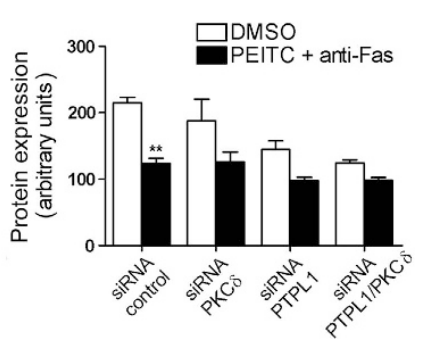

Figure 5 Signal transduction pathways regulated by PTPL1. PC3 cells were silenced with non-targeting control, PTPL1, PKC $\delta$ and both PTPL1 and PKC $\delta$ siRNAs. To ensure an equal quantity of siRNAs in all conditions, non-targeting control siRNA was added at $100 \mathrm{nM}$ in individual non-targeting control, PTPL1 and PKC $\delta$ siRNAs. Cells were then treated with DMSO or $10 \mu \mathrm{M}$ PEITC for $1 \mathrm{~h}$ plus $0.5 \mu \mathrm{g} / \mathrm{ml}$ anti-Fas for $16 \mathrm{~h}$. (a) Apoptosis detection by flow cytometry of annexin V and propidium iodide-labelled cells. (b) Detection of the indicated proteins was performed by western blot. $\beta$-Actin is shown as loading control. Densitometric analysis of each protein is shown as histograms. Data are presented as mean \pm S.E.M. $(n=3)$. ${ }^{*} P<0.05$ and ${ }^{* *} P<0.01$ from Student's $t$ test, comparing treated cells for each siRNA condition versus treated siRNA control cells, in the case of cleaved PARP and caspases and, for the rest of proteins, untreated versus treated PC 3 cells for each siRNA condition. The experiment was performed at least three times

treated PTPL1 transfected cells and $65.6 \%$ in treated PKC $\delta$ transfected cells) (Figure 6a). In line with this result, the increase in PTPL1 expression significantly enhanced PARP cleavage upon treatment (Figure 6b) $(P<0.05)$.
$\mathrm{PKC} \delta$-transfected PC3 cells treated in the same way also showed more PARP cleavage than empty vector-transfected cells (Figure 6b) $(P<0.05)$. NF- $\kappa \mathrm{B}$ phosphorylation was almost undetectable in treated PTPL1 or PKC $\delta$-transfected 
PC3 cells (Figure 6b), supporting siRNA results. Then, PC3 cells were simultaneously transfected with PTPL1 and silenced for $\mathrm{PKC} \delta$, and treated with PEITC and anti-Fas, to test whether the increased apoptosis obtained after PTPL1 transfection could be reversed by $\mathrm{PKC} \delta$ silencing. As observed in Figure 6c, PARP cleavage decreases in treated cells transfected with PTPL1 and silenced for $\mathrm{PKC} \delta$, as

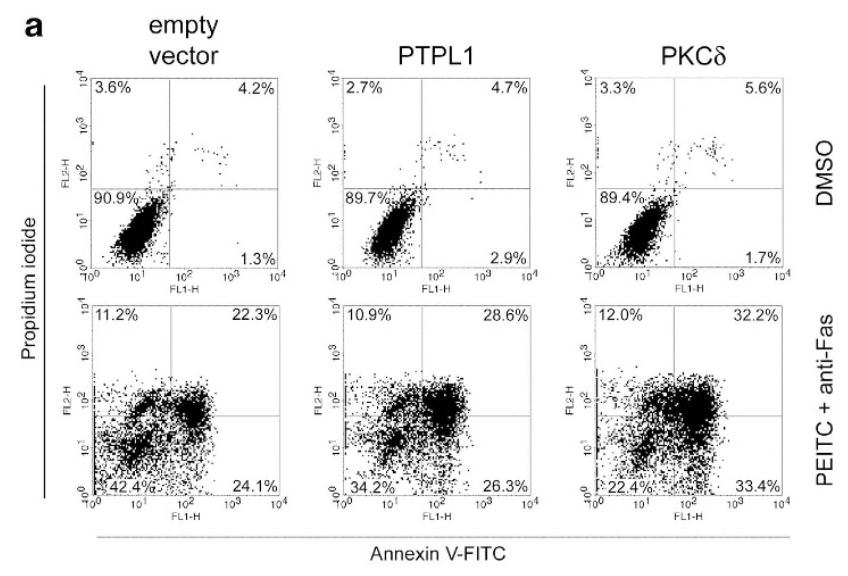

b
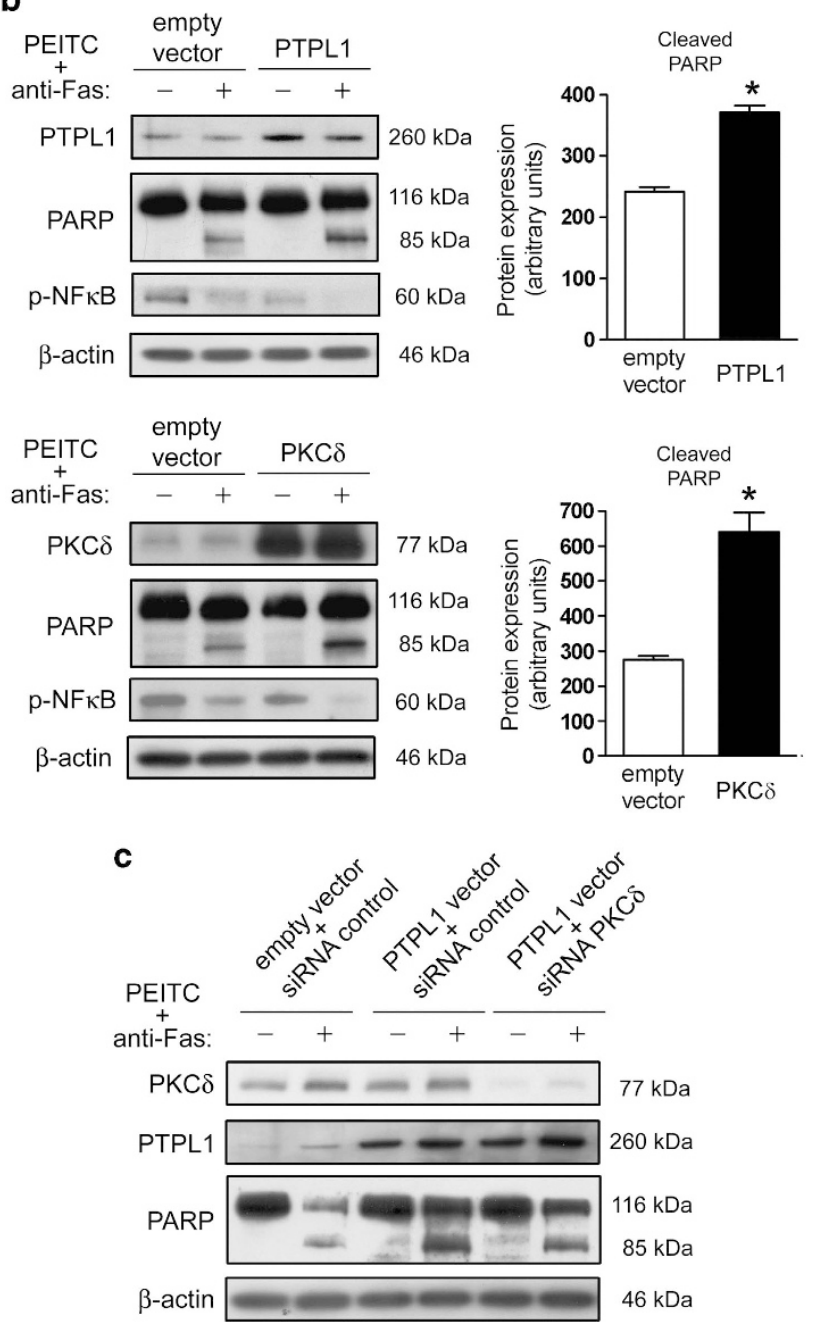

compared with PTPL1-transfected cells, highlighting again the relevance of $\mathrm{PKC} \delta$ in PTPL1-mediated signalling in this cell line. Finally, to test whether the increase in apoptosis observed in PEITC and anti-Fas-treated PTPL1 or PKC $\delta$ transfected cells also occurs with other stimuli, transfected cells were treated with paclitaxel. Both paclitaxel-treated PTPL1 and PKC $\delta$-transfected cells showed increased PARP cleavage after treatment (Supplementary Figure S3).

PTPL1 or PKC $\delta$ silencing induces apoptosis resistance in LNCaP cells. To ascertain whether these findings could be extended to another prostate cancer cell line, PTPL1 and PKC $\delta$ were downregulated by siRNA in LNCaP cells. Silenced cells were then treated with PEITC and anti-Fas and apoptosis induction was assessed by PARP cleavage (Figure 7). PTPL1-silenced LNCaP cells were more resistant to apoptosis induction than siRNA control cells, with differences in PARP cleavage being statistically significant $(P<0.05)$ (Figure 7a). LNCaP cells silenced for PKC $\delta$ also showed apoptosis resistance after treatment $(P<0.05)$ (Figure $7 \mathrm{~b}$ ). Next, we examined NF- $\kappa \mathrm{B}$ activation status in this setting to test whether PTPL1 and $\mathrm{PKC} \delta$ influence $\mathrm{NF}-\kappa \mathrm{B}$ signalling. NF- $\kappa \mathrm{B}$ phosphorylation was diminished in both treated siRNA PTPL1 and PKC $\delta$ cells, in a similar way as treated siRNA control cells (Figure 7b); thus, PTPL1 and $\mathrm{PKC} \delta$ do not seem to influence NF- $\kappa \mathrm{B}$ phosphorylation in this cell line. Then, the same experimental approach but using paclitaxel was performed. Both paclitaxel-treated PTPL1 and $\mathrm{PKC} \delta$ silenced cells show diminished PARP cleavage, as compared with treated siRNA control cells (Supplementary Figure S4), but differences were only statistically significant in the case of siRNA PKC $\delta$ cells $(P<0.05)$.

PTPL1 and PKC $\delta$ immunohistochemical expression in prostate cancer tissues. We performed an immunohistochemical analysis of PTPL1 and $\mathrm{PKC} \delta$ expression in 76 prostate cancer biopsies (Figure 8). Tumour glands showed different degrees of cytoplasmic immunostaining for PTPL1. Well-differentiated, low Gleason score tumours showed strong PTPL1 positivity, whereas poorly differentiated, high Gleason score tumours were either weakly or not immunostained. Statistical analysis showed a significant association $(P<0.05)$ between PTPL1 immunohistochemical expression and Gleason score. Immunostaining for PKC $\delta$ showed a similar pattern as well-differentiated, low Gleason score tumours showed significantly higher levels of PKC $\delta$ expression than poorly differentiated, high Gleason score tumours $(P<0.01)$.

Figure 6 PTPL1 or PKC $\delta$ overexpression sensitizes PC3 cells to PEITC and anti-Fas induced apoptosis. (a and $\mathbf{b})$ PC3 cells were transiently transfected with empty vector, PTPL1 or PKC $\delta$ plasmids and treated with $10 \mu \mathrm{M}$ PEITC for $1 \mathrm{~h}$ plus $0.5 \mu \mathrm{g} / \mathrm{ml}$ anti-Fas for $16 \mathrm{~h}$. (a) Apoptosis was assessed by flow cytometry of annexin $\mathrm{V}$ and propidium iodide-labelled cells. (b) Detection of the indicated proteins was performed by western blot. $\beta$-Actin is shown as loading control. Densitometric analysis of cleaved PARP is shown as histograms. Data are presented as mean \pm S.E.M. $(n=3)$. ${ }^{*} P<0.05$ and ${ }^{* *} P<0.01$ from Student's $t$ test. (c) PC 3 cells were co-transfected with empty vector and siRNA control, with PTPL1 plasmid and siRNA control or with PTPL1 plasmid and siRNA PKC $\delta$. Cells were then treated with $10 \mu \mathrm{M}$ PEITC for $1 \mathrm{~h}$ plus $0.5 \mu \mathrm{g} / \mathrm{ml}$ anti-Fas for $16 \mathrm{~h}$. Detection of the indicated proteins was performed by western blot. $\beta$-Actin is shown as loading control. The experiments were performed at least three times 
a
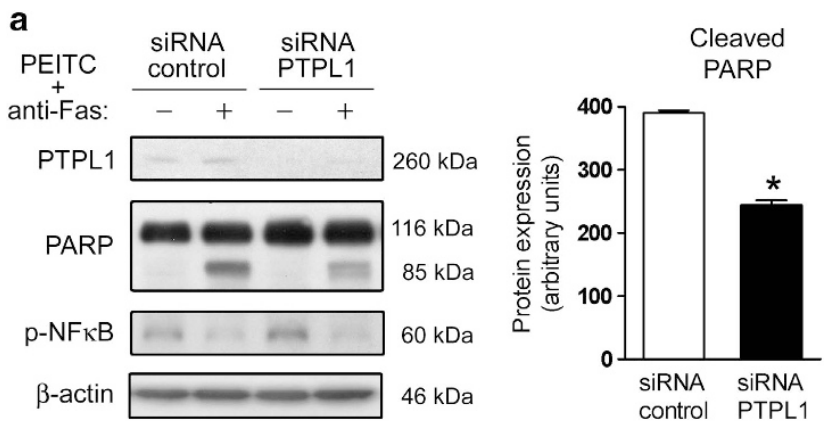

b

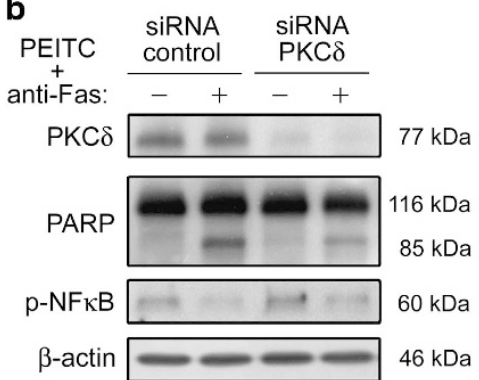

Figure 7 PTPL1 or PKC $\delta$ silencing promotes apoptosis resistance in LNCaP cells. LNCaP cells were silenced with non-targeting control, PTPL1, (a) or PKC $\delta$ (b) siRNAs and treated with $10 \mu \mathrm{M}$ PEITC for $1 \mathrm{~h}$ plus $0.5 \mu \mathrm{g} / \mathrm{ml}$ anti-Fas for $16 \mathrm{~h}$. Detection of the indicated proteins was performed by western blot. $\beta$-Actin is shown as loading control. Densitometric analysis of cleaved PARP is shown as histograms. Data are presented as mean \pm S.E.M. $(n=3)$. ${ }^{*} P<0.05$ from Student's $t$ test. The experiments were performed at least three times

\section{Discussion}

Several studies have demonstrated that different compounds can sensitize prostate cancer cells to Fas-induced apoptosis. ${ }^{15,21,22}$ In the case of PEITC, a sensitizing effect on Fasmediated apoptosis has been reported in T24 bladder cancer cells and in Jurkat cells overexpressing $\mathrm{Bcl}-2 .^{23}$ We have observed that the treatment with PEITC also sensitizes PC3 cells to anti-Fas induced apoptosis and that the extent of apoptosis caused by this treatment was higher than that achieved with any of the compounds alone. Protein tyrosine phosphorylation is a major regulator of signal transduction in higher eukaryotes. ${ }^{4}$ PTPL1 is the largest non-receptor protein tyrosine phosphatase and its function in apoptosis regulation is a matter of debate. There is some evidence suggesting that PTPL1 may act as a negative regulator of apoptosis and as a tumour promoting gene, while other studies point towards a role for PTPL1 as a positive regulator of apoptosis and as a tumour suppressor. ${ }^{4}$ Specifically in prostate cancer, two studies concerning sensitivity to Fas-mediated apoptosis of prostate cancer cell lines failed to find a correlation between resistance to Fas-mediated apoptosis and increased expression of PTPL1 at the mRNA level, ${ }^{15,16}$ but functional studies are lacking in prostate cancer addressing the role of PTPL1 in apoptosis. In this study, we have determined a proapoptotic role for PTPL1 in PC3 prostate cancer cells, as its overexpression promotes apoptosis in cells treated with PEITC and anti-Fas simultaneously or paclitaxel and its downregulation induces apoptosis resistance upon treatment with
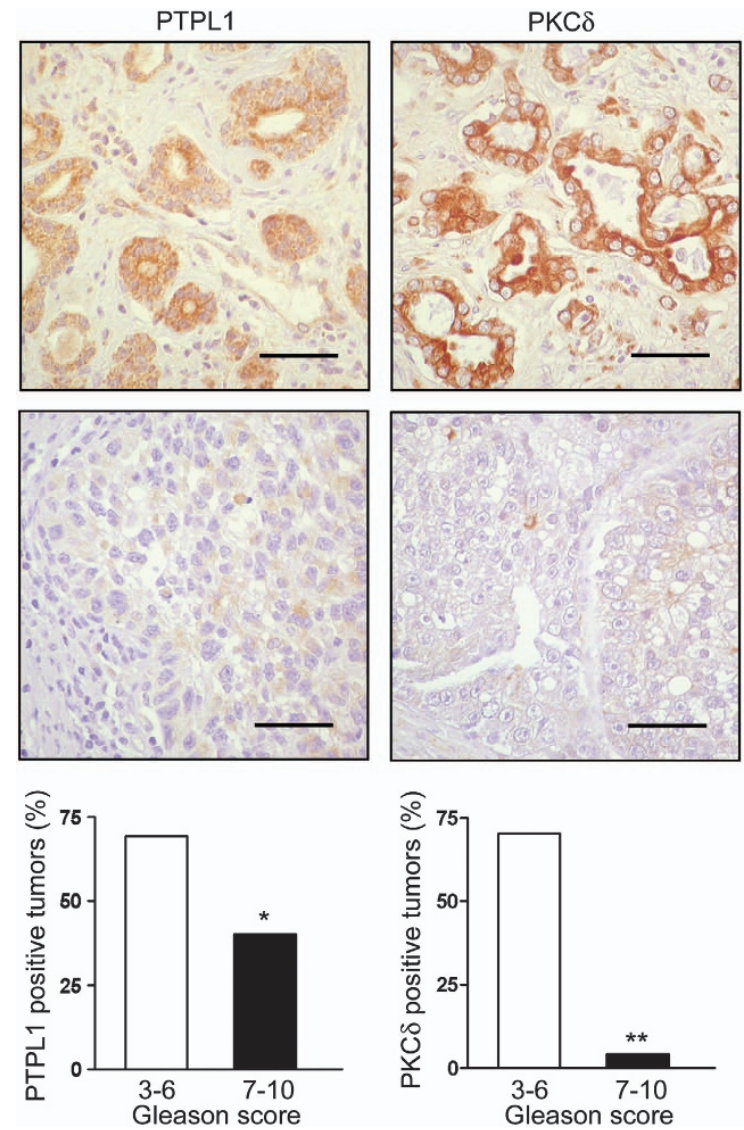

Figure 8 Immunohistochemical expression of PTPL1 and PKC $\delta$ in human prostate cancers. Representative micrographs of PTPL1 and PKC $\delta$ immunoperoxidase staining of well-differentiated, low Gleason score (top), and poorly differentiated, high Gleason score (bottom) prostatic carcinomas. Bars, $50 \mu \mathrm{m}$. Histograms show percent of positive tumours of Gleason scores 3-6 (well differentiated) and Gleason scores 7-10 (poorly differentiated) for PTPL1 and PKC $\delta$ expression. Association between PKC $\delta$ or PTPL1 and Gleason grade was analysed by Fisher's exact test. ${ }^{*} P<0.05$ and ${ }^{* *} P<0.01$

these agents. Interestingly, PTPL1 silencing is also associated with diminished apoptosis in $\mathrm{LNCaP}$ cells treated with PEITC and anti-Fas.

In the case of siRNA control and siRNA PTPL1 PC3 cells treated with PEITC and anti-Fas, changes in Bcl-2 family proteins were a slight induction of $\mathrm{Bcl}-\mathrm{xL}$ in PTPL1 silenced cells and an increase in proapoptotic $\mathrm{Mcl}-1_{\mathrm{S}}$ and in the $24-\mathrm{kDa}$ cleaved fragment of $\mathrm{Mcl}-1_{\mathrm{L}}$ in siRNA control-treated cells. It has been suggested that caspase-cleaved fragment(s) of Mcl-1 lose anti-apoptotic potential and become proapoptotic or alternatively, that $\mathrm{Mcl}-1$ cleavage may disrupt the protective function of the protein. ${ }^{24}$ Taken together, these results suggest that a PTPL1-mediated signalling pathway could influence the expression levels of $\mathrm{Bcl}-\mathrm{xL}$ and $\mathrm{Mcl}-1_{S}$ proteins as well as final events in the apoptotic process such as activation of caspases and subsequently, caspase-mediated cleavage of proteins like Mcl-1 or PARP.

PKC family of serine/threonine kinases is activated by diverse stimuli and participates in many cellular processes. Most studies indicate that $\mathrm{PKC} \delta$ isoform is involved in 
suppression of cell proliferation and induction of apoptosis, but there are a few studies pointing to a role of $\operatorname{PKC} \delta$ in cell survival and anti-apoptotic responses. ${ }^{25}$ In relation to prostate cancer, some studies point towards a role of $\mathrm{PKC} \delta$ in migration and invasion, ${ }^{26,27}$ while others have reported that expression of $\operatorname{PKC} \delta$ is required in anticancer drugs or death receptor-induced apoptosis. ${ }^{28-30}$ In this sense, we have observed that $\mathrm{PKC} \delta$ overexpression increases the apoptosis induction by PEITC and anti-Fas or paclitaxel in PC3 cells. It has been established that $\mathrm{PKC} \delta$ mediates paclitaxel, etoposide $^{29}$ or phorbol ester-induced apoptosis in LNCaP cells; ${ }^{30}$ according to these data, $\mathrm{PKC} \delta$ silencing induces apoptosis resistance upon treatment with PEITC and anti-Fas or paclitaxel in LNCaP cells. We conclude that PKC $\delta$ and PTPL1 seem to exert a proapoptotic function in both androgensensitive LNCaP cells and androgen-resistant PC3 cells, although the signalling events involved in the apoptotic process differ between both cell lines.

$\mathrm{PKC} \delta$ activity is regulated by binding of cofactors to the regulatory region and by phosphorylation on its kinase domain, especially on its activation loop, but the dependence of $\mathrm{PKC} \delta$ activity on its activation loop phosphorylation is still controversial. ${ }^{17}$ Interestingly, a study has shown that a mutant activation loop non-phosphorylated $\operatorname{PKC} \delta$ is catalytically active in cells, but its pattern of substrate phosphorylation and function is markedly changed. Notably, this mutant PKC $\delta$ is as active as wild-type PKC $\delta$ in induction of apoptosis. ${ }^{18} \mathrm{We}$ have observed that in PC3 cells expressing endogenous PTPL1, PKC $\delta$ phosphorylation at T505 (located within the activation loop) is clearly diminished upon treatment with PEITC and anti-Fas, whereas treated cells silenced for PTPL1 sustain the basal level of $\mathrm{PKC} \delta$ phosphorylation. It was confirmed as well that the loss of PKC $\delta$ T505 phosphorylation in the presence of PTPL1 also occurs when PEITC or paclitaxel is used to induce apoptosis. It is interesting to note that the loss of $\mathrm{PKC} \delta$ T505 phosphorylation only occurs in cells undergoing apoptosis, so the question arises whether the loss of phosphorylation means a loss of activity of the kinase and resembles a loss of the protein, or if the presence of T505 dephosphorylated PKC $\delta$ via PTPL1 is relevant for the induction of apoptosis. The latter question was confirmed, since the silencing of $\mathrm{PKC} \delta$ by siRNA induces apoptosis resistance in PC3 cells. Furthermore, the simultaneous silencing of PTPL1 and $\mathrm{PKC} \delta$ causes even a greater apoptosis resistance than any of them separately, supporting the notion that the presence of both proteins is necessary for a better efficiency of the apoptotic process. Thus, we have shown that PC3 cells are more sensitive to apoptosis induction by PEITC and anti-Fas in the presence of both $\mathrm{PKC} \delta$ and PTPL1, that $\mathrm{PKC} \delta$ is primarily unphosphorylated at T505 in cells undergoing apoptosis triggered by diverse stimuli and that the loss of T505 phosphorylation of $\mathrm{PKC} \delta$ may be mediated, probably indirectly, by PTPL1. As mentioned above, a mutant $\mathrm{PKC} \delta$ lacking activation loop phosphorylation has been reported to be as active as wild-type PKC $\delta$ in the induction of apoptosis but displays a substrate-selective defect in phosphorylation when co-targeted with substrates in the cell and it is defective in activity in AP-1 and NF- $\kappa \mathrm{B}$ reporter assays that require kinase activity. ${ }^{18} \mathrm{NF}-\kappa \mathrm{B}$ mediates mainly anti-apoptotic signals in prostate cancer, ${ }^{31}$ so we investigated its activation status. Treatment of PC3 cells with PEITC and anti-Fas has hardly any effect on NF- $\kappa \mathrm{B}$ phosphorylation when PKC $\delta$ or both PTPL1 and $\mathrm{PKC} \delta$ are silenced. However, in treated cells expressing endogenous PTPL1 and $\mathrm{PKC} \delta$, in which $\mathrm{PKC} \delta$ is primarily unphosphorylated at T505, active NF- $\kappa \mathrm{B}$ (phosphorylated) is lower than in treated cells expressing endogenous $\mathrm{PKC} \delta$ but silenced for PTPL1, with PKC $\delta$ phosphorylated at T505. According to these data, NF- $\kappa \mathrm{B}$ dephosphorylation is achieved more efficiently when T505 dephosphorylated $\mathrm{PKC} \delta$, via PTPL1, is present. Immunofluorescence studies also revealed a nuclear accumulation of $\mathrm{NF}-\kappa \mathrm{B}$ in $\mathrm{PC} 3$ cells silenced for PTPL1 or PKC $\delta$ treated with PEITC and antiFas, supporting the notion of increased NF- $\kappa$ B activation under these conditions. Moreover, PTPL1 or PKC $\delta$ overexpression leads to decreased NF- $\kappa$ B activation after PEITC and anti-Fas treatment in PC3 cells, corroborating again the influence of PTPL1 and $\mathrm{PKC} \delta$ in NF- $\kappa \mathrm{B}$ signalling. Nonetheless, in the case of LNCaP cells, NF- $\kappa$ B phosphorylation diminishes in PEITC and anti-Fas-treated siRNA PTPL1 and siRNA $\mathrm{PKC} \delta$ cells, thus suggesting the involvement of alternative pathways in PTPL 1 and $\operatorname{PKC} \delta$-mediated signalling in LNCaP cells.

The phosphorylation status of $I_{\kappa} \mathrm{B} \alpha$, a negative regulator of $\mathrm{NF}-\kappa \mathrm{B}$ activity, was also examined. $I_{\kappa} \mathrm{B} \alpha$ phosphorylation on serines 32 and 36 leads to its ubiquitination and degradation, which in turn promotes the translocation of NF- $\kappa \mathrm{B}$ from the cytoplasm to the nucleus, where it becomes an active transcription factor. $\left.{ }^{31}\right|_{\kappa} \mathrm{B} \alpha$ phosphorylation on tyrosine 42 also induces $\mathrm{l} \kappa \mathrm{B} \alpha$ dissociation from $\mathrm{NF}-\kappa \mathrm{B}$, but without proteolytic degradation ${ }^{20}$ and, interestingly, it has been shown that phosphorylated $\mathrm{I} \kappa \mathrm{B} \alpha$ at $\mathrm{Y} 42$ is a substrate of PTPL1 in vitro. ${ }^{32}$ We have observed that, in PC3 cells treated with PEITC and anti-Fas expressing endogenous PTPL1 and $\mathrm{PKC} \delta$, I $\kappa \mathrm{B} \alpha$ undergoes extensive dephosphorylation on S32, S36, and Y42. However, when PKC $\delta$, PTPL1 or both are silenced, dephosphorylation on the three sites upon drug treatment is impaired. It has been reported that PEITC inhibits $I_{\kappa} \mathrm{B} \alpha$ phosphorylation and decreases the nuclear translocation of $\mathrm{p} 65$ subunit of $\mathrm{NF}-\kappa \mathrm{B} ;{ }^{13}$ thus, based on this previous work and on the above-mentioned results, we propose that inhibition of $\mathrm{I} \kappa \mathrm{B} \alpha$ degradation and suppression of $\mathrm{NF}-\kappa \mathrm{B}$ activity (by both $\mathrm{I} \kappa \mathrm{B} \alpha$ association and dephosphorylation) could be mediated, at least in part, by PTPL1 and PKC $\delta$, and that these signalling events contribute to apoptosis in PC3 prostate cancer cells.

Akt is a serine/threonine kinase that promotes cancer cell survival and mediates mainly anti-apoptotic signalling. ${ }^{33}$ PTPL1 has been shown to inhibit Akt phosphorylation, ${ }^{6}$ while others fail to find such a correlation. ${ }^{7}$ We have detected diminished Akt basal phosphorylation in PC3 cells silenced for PTPL1; however, Akt phosphorylation levels decrease after treatment either in the presence or in the absence of PTPL1 or $\operatorname{PKC} \delta$. The ability of PEITC and anti-Fas treatment to downregulate phosphorylated Akt in all conditions tested could indicate that PTPL1 and $\operatorname{PKC} \delta$ are not required to dephosphorylate Akt.

PKC $\delta$ immunohistochemical expression in prostate cancers is also controversial. A study of 23 prostate cancer specimens reported that $\mathrm{PKC} \delta$ was only expressed by stroma 
but not by epithelium. ${ }^{34}$ However, others have found a high expression of $\mathrm{PKC} \delta$ in the epithelial component of prostate cancers, ${ }^{26,27}$ irrespective of the Gleason score. ${ }^{26}$ PTPL1 immunohistochemical expression has not yet been assessed in prostate cancers. We have found in a statistically significant way that immunohistochemical expression of both PTPL1 and $\mathrm{PKC} \delta$ in prostate cancer tissues is higher in well-differentiated, low Gleason score tumours than in poorly differentiated, high Gleason score tumours. In this sense, PTPL1 expression at the mRNA level has been found to be an independent favourable prognostic indicator for overall survival in patients with breast cancer. ${ }^{35}$ Loss of these proteins in prostate tumours of less favourable prognosis also indicates that their absence could be related to apoptosis resistance and tumour progression.

\section{Materials and Methods}

Cell culture and plasmid transfections. Human prostate cancer PC3 and LNCaP cell lines were obtained from the Interlab Cell Line Collection (Genoa, Italy). All the experiments were done using vials from the first 10 passages after receipt. Cells were routinely grown in RPMI- 1640 supplemented with $10 \%$ heatinactivated fetal bovine serum, $100 \mathrm{U} / \mathrm{ml}$ penicillin, $100 \mu \mathrm{g} / \mathrm{ml}$ streptomycin, $10 \mathrm{mM}$ HEPES buffer and $1 \mathrm{mM}$ glutamine in a $37^{\circ} \mathrm{C}$, humidified incubator under $5 \% \mathrm{CO}_{2}$. Cells were harvested by trypsinization. Transient transfections with $\mathrm{PCMV6-XL4-}$ PTPL1 or pCMV6-XL5-PKC $\delta$ plasmids (Origene, Rockville, MD, USA), were carried out using the FuGENE reagent (Promega, Madison, WI, USA), according to manufacturer's instructions. Cells were subjected to different treatments 24 or $48 \mathrm{~h}$ after transfection.

Small interfering RNA. siRNA transfections were carried out using the Dharmafect reagent (Thermo Fisher Dharmacon, Lafayette, CO, USA) according to manufacturer's instructions. The PTPL1-specific siRNA and the control-negative siRNA were from Qiagen (Hilden, Germany). PKC $\delta$-specific siRNA was from Thermo Fisher Dharmacon. All siRNAs were used at $100 \mathrm{nM}$. Cells were subjected to different treatments 24 or $48 \mathrm{~h}$ after silencing.

Antibodies. Rabbit polyclonal anti-Bax and anti-Bak were available from BD Biosciences (San Jose, CA, USA). Mouse monoclonal anti-Bcl-xL, rabbit polyclonal anti-Mcl-1, rabbit polyclonal anti-PTPL1, rabbit polyclonal anti-I $\kappa B \alpha$, and rabbit polyclonal anti-NF- $\kappa$ Bp65 antibodies were from Santa Cruz Biotechnology (Santa Cruz, CA, USA); mouse monoclonal anti- $\beta$-actin from Sigma (St Louis, MO, USA). Rabbit polyclonal anti-phospho-PKC $\delta$ (Thr505), antiphospho-Akt (Ser473), and anti-PKC $\delta$ antibodies were from Cell Signaling (Danvers, MA, USA). A second rabbit polyclonal anti-PKC $\delta$ used in immunohistochemical procedures was from Abcam (Cambridge, UK). Rabbit polyclonal anti-cleaved caspase 3, anti-phospho- $\kappa_{\kappa} \mathrm{B} \alpha$ (S32/36), anti-phospho$\mathrm{I}_{\kappa} \mathrm{B} \alpha(\mathrm{Y} 42)$, and anti-phospho-NF- $\kappa \mathrm{Bp} 65$ (S276) antibodies were from Abcam. Rabbit polyclonal anti-cleaved caspase 7 (Asp198) and anti-cleaved caspase 9 (Asp315) antibodies were from Calbiochem (San Diego, CA, USA). Dilutions used in western blots were anti-Bax (1:1000); anti-Bak (1:2000); anti-Bcl-xL (1:200); anti- $\beta$-actin (1:20000); anti-PTPL1 (1:500); anti-phospho-PKC $\delta$ (Thr505) (1:150); anti-PKC $\delta$ (1:200); anti-phospho-Akt (Ser473) (1:400); anti-phospho$I_{\kappa} \mathrm{B} \alpha \quad(\mathrm{S} 32 / 36) \quad(1: 300) ;$ anti-phospho- $\left.\right|_{\kappa} \mathrm{B} \alpha$ (Y42) $(1: 200) ;$ anti-phosphoNF- $\kappa$ Bp65 (S276) (1:500); anti-I $\kappa \mathrm{B} \alpha(1: 500)$; anti-NF- $\kappa$ Bp65 (1:500); anti-cleaved caspase 3 (1:200); anti-cleaved caspase 7 (1:1000); and anti-cleaved caspase $9(1: 500)$. Caspase-mediated cleavage of PARP was assessed by western blot using a mouse monoclonal anti-human PARP (BD Biosciences) at 1:250 dilution.

Western blotting. Cells were lysed in Nonidet P-40 (NP-40) lysis buffer (10 mM Tris- $\mathrm{HCl}(\mathrm{pH} 7.5), 150 \mathrm{mM} \mathrm{NaCl}, 10 \%$ glycerol and 1\% NP-40). Equal amounts of total protein, as determined by using BCA protein assay (Pierce, Rockford, IL, USA), were separated by SDS-PAGE on 4-20\% gradient polyacrylamide gels (Invitrogen, Carlsbad, CA). Gels were electroblotted onto nitrocellulose membranes (GE Healthcare, Little Chalfont, UK). Membranes were stained with Ponceau $S$ to ensure that protein amounts were comparable. For immunodetection, blots were blocked in $1 \%$ blocking reagent (Roche, Mannheim,
Germany) in $0.05 \%$ Tween 20 -PBS for $1 \mathrm{~h}$ and incubated with primary antibody overnight at $4{ }^{\circ} \mathrm{C}$ diluted in blocking buffer. Blots were then washed in $0.05 \%$ Tween 20-PBS and incubated with either goat anti-mouse (1:10000; GE Healthcare) or goat anti-rabbit (1:20000; GE Healthcare) peroxidase-labelled antibodies in blocking buffer for $1 \mathrm{~h}$. Enhanced chemoluminescent system was applied according to manufacturer's protocol (GE Healthcare). Scanning densitometry was performed with QuantiScan software (Biosoft, Cambridge, UK). Arbitrary densitometric units of the proteins of interest were corrected for those of $\beta$-actin. Data comparing differences between two conditions were statistically analysed, when indicated, using paired Student's t-test. Differences were considered as significant when $P<0.05$.

Tumour immunohistochemistry. Prostate cancer tissue microarray comprised 76 formalin-fixed, paraffin-embedded primary prostate tumour cases selected from diagnostic radical prostatectomy specimens collected at our Hospital, with institutional ethical board approval. Two independent pathologists evaluated Gleason score according to conventional criteria. ${ }^{36}$ Immunohistochemistry was performed as previously described. ${ }^{37}$ For PTPL1 antibody, antigen retrieval was performed with a microwave, using $1 \mathrm{mM}$ EDTA pH 9.0 and, for $\mathrm{PKC} \delta$, with $1 \mathrm{mg} / \mathrm{ml}$ trypsin, $15 \mathrm{~min}$ at $37^{\circ} \mathrm{C}$. Immunostaining was evaluated independently by two observers and scored positive if $>25 \%$ of carcinoma cells were intensely stained. Association between PTPL1 or PKC $\delta$ immunohistochemical expression and Gleason grade was analysed by Fisher's exact test. Differences were considered as significant when $P<0.05$.

Apoptosis induction and assays. Stock solutions of PEITC (Sigma) and paclitaxel (Calbiochem) were prepared at $10 \mathrm{mM}$ in DMSO (dimethyl sulfoxide, Sigma) and stored frozen. Monoclonal anti-Fas antibody clone $\mathrm{CH} 11$ was from Beckman Coulter (Fullerton, CA, USA). Annexin V binding assays were carried out as previously reported ${ }^{37}$ using a FACScan flow cytometer (BD Biosciences). In all the experiments, DMSO was added to untreated cells.

Reverse-transcription and quantitative PCR. Total RNA was extracted using the Purescript RNA Isolation Kit (Gentra, Minneapolis, MN, USA) according to manufacturer's protocol. In all, $0.5 \mu \mathrm{g}$ of total RNA was subjected to DNase I (Invitrogen) digestion and subsequently processed to CDNA by reverse transcription with Transcriptor First Strand cDNA Synthesis Kit (Roche) according to manufacturer's protocol. PCRs were performed in a $25-\mu$ l reaction volume on the SmartCycler II Real-Time PCR Detection System (Cepheid, Sunnyvale, CA, USA) using the QuantiMix Easy SyG kit (Biotools, Madrid, Spain) and $500 \mathrm{nM}$ of each specific primer. The levels of PTPL1 and the housekeeping gene RPL13A in each sample were quantified by measuring the Ct values in duplicate. These mean $\mathrm{Ct}$ values were transformed to quantities using the delta-Ct method. The sample with the lowest value was assigned the value 1 . The quantity of PTPL1 transcript was divided by the quantity of RPL13A to obtain a normalized value.

\section{Conflict of Interest}

The authors declare no conflict of interest.

Acknowledgements. We thank M Tortolero, F Romero, M Mora-Santos, S Giráldez, and J Herrero-Ruiz for their support. This work was supported by grants from the Instituto de Salud Carlos III (FIS PI10/02026, ISCIII-RETIC-RD06/0020FEDER) and Ministerio de Ciencia e Innovación, Spain (SAF2011-30003-C02-02), Consejería de Salud (PI-2009-0589, Al-2012-SA001) and Consejería de Innovación, Ciencia y Empresa, Junta de Andalucía (CTS-6243). CC was supported by a pre-doctoral grant from the Spanish Ministerio de Educación (F.P.I.: BES200612419) co-financiated by Fondo Social Europeo. CS was supported by a contract from Programa Monardes, Consejería de Salud, Junta de Andalucía. The authors have nothing to disclose.

1. Uzgare AR, Isaacs JT. Prostate cancer: potential targets of anti-proliferative and apoptotic signaling pathways. Int J Biochem Cell Biol 2005; 37: 707-714.

2. Scaffidi C, Fulda S, Srinivasan A, Friesen C, Li F, Tomaselli KJ et al. Two CD95 (APO-1/ Fas) signaling pathways. EMBO J 1998; 17: 1675-1687.

3. Guseva NV, Taghiyev AF, Rokhlin OW, Cohen MB. Contribution of death receptor and mitochondrial pathways to Fas-mediated apoptosis in the prostatic carcinoma cell line PC3. Prostate 2002; 51: 231-240. 
4. Abaan OD, Toretsky JA. PTPL1: a large phosphatase with a split personality. Cancer Metastasis Rev 2008; 27: 205-214.

5. Bompard G, Puech C, Prébois C, Vignon F, Freiss G. Protein-tyrosine phosphatase PTPL1/FAP-1 triggers apoptosis in human breast cancer cells. J Biol Chem 2002; 277 : 47861-47869.

6. Dromard M, Bompard G, Glondu-Lassis M, Puech C, Chalbos D, Freiss G. The putative tumor suppressor gene PTPN13/PTPL1 induces apoptosis through insulin receptor substrate-1 dephosphorylation. Cancer Res 2007; 67: 6806-6813.

7. Miyazaki T, Atarashi $\mathrm{Y}$, Yasumura S, Minatoya I, Ogawa $\mathrm{K}$, Iwamoto $\mathrm{M}$ et al. Fasassociated phosphatase-1 promotes Fas-mediated apoptosis in human colon cancer cells: novel function of FAP-1. J Gastroenterol Hepatol 2006; 21: 84-91.

8. Fahey JW, Zalcmann AT, Talalay P. The chemical diversity and distribution of glucosinolates and isothiocyanates among plants. Phytochemistry 2001; 56: 5-51.

9. Xiao D, Johnson CS, Trump DL, Singh SV. Proteasome-mediated degradation of cell division cycle $25 \mathrm{C}$ and cyclin-dependent kinase 1 in phenethyl isothiocyanate-induced G2-M-phase cell cycle arrest in PC-3 human prostate cancer cells. Mol Cancer Ther 2004; 3: $567-575$.

10. Xiao D, Singh SV. Phenethyl isothiocyanate-induced apoptosis in p53-deficient PC-3 human prostate cancer cell line is mediated by extracellular signal-regulated kinases. Cancer Res 2002; 62: 3615-3619.

11. Xiao D, Lew KL, Zeng Y, Xiao H, Marynowski SW, Dhir R et al. Phenethyl isothiocyanateinduced apoptosis in PC-3 human prostate cancer cells is mediated by reactive oxygen species-dependent disruption of the mitochondrial membrane potential. Carcinogenesis 2006; 27: 2223-2234.

12. Xiao D, Zeng Y, Choi S, Lew KL, Nelson JB, Singh SV. Caspase-dependent apoptosis induction by phenethyl isothiocyanate, a cruciferous vegetable-derived cancer chemopreventive agent, is mediated by Bak and Bax. Clin Cancer Res 2005; 11: 2670-2679.

13. Xu C, Shen G, Chen C, Gélinas C, Kong AN. Suppression of NF-kappaB and NF-kappaBregulated gene expression by sulforaphane and PEITC through IkappaBalpha, IKK pathway in human prostate cancer PC-3 cells. Oncogene 2005; 24: 4486-4495.

14. Rokhlin OW, Bishop GA, Hostager BS, Waldschmidt TJ, Sidorenko SP, Pavloff N et al. Fas-mediated apoptosis in human prostatic carcinoma cell lines. Cancer Res 1997; 57: 1758-1768.

15. Uslu R, Borsellino N, Frost $\mathrm{P}$, Garban $\mathrm{H}, \mathrm{Ng} \mathrm{C}$, Mizutani $Y$ et al. Chemosensitization of human prostate carcinoma cell lines to anti-Fas-mediated cytotoxicity and apoptosis. Clin Cancer Res 1997; 3: 963-972.

16. Hedlund TE, Duke RC, Schleicher MS, Miller GJ. Fas-mediated apoptosis in seven human prostate cancer cell lines: correlation with tumor stage. Prostate 1998; 36: 92-101.

17. Steinberg SF. Distinctive activation mechanisms and functions for protein kinase $C$ delta. Biochem J 2004; 384: 449-459.

18. Liu Y, Belkina NV, Graham C, Shaw S. Independence of protein kinase C-delta activity from activation loop phosphorylation: structural basis and altered functions in cells. J Biol Chem 2006; 281: 12102-12111.

19. Joo JH, Jetten AM. NF-kappaB-dependent transcriptional activation in lung carcinoma cells by farnesol involves p65/RelA(Ser276) phosphorylation via the MEK-MSK1 signaling pathway. J Biol Chem 2008; 283: 16391-16399.

20. Fan C, Yang J, Engelhardt JF. Temporal pattern of NFkappaB activation influences apoptotic cell fate in a stimuli-dependent fashion. J Cell Sci 2002; 115: 4843-4853.

21. Gill C, Walsh SE, Morrissey C, Fitzpatrick JM, Watson RW. Resveratrol sensitizes androgen independent prostate cancer cells to death-receptor mediated apoptosis through multiple mechanisms. Prostate 2007; 67: 1641-1653.
22. Taghiyev AF, Guseva NV, Sturm MT, Rokhlin OW, Cohen MB. Trichostatin A (TSA) sensitizes the human prostatic cancer cell line DU145 to death receptor ligands treatment. Cancer Biol Ther 2005; 4: 382-390.

23. Pullar JM, Thomson SJ, King MJ, Turnbull Cl. Midwinter RG, Hampton MB. The chemopreventive agent phenethyl isothiocyanate sensitizes cells to Fas-mediated apoptosis. Carcinogenesis 2004; 25: 765-772.

24. Zhuang J, Brady HJ. Emerging role of Mcl-1 in actively counteracting BH3-only proteins in apoptosis. Cell Death Differ 2006; 13: 1263-1267.

25. Jackson DN, Foster DA. The enigmatic protein kinase $C$ delta: complex roles in cell proliferation and survival. FASEB J 2004; 18: 627-636.

26. Villar J, Arenas MI, MacCarthy CM, Blánquez MJ, Tirado OM, Notario V. PCPH/ENTPD5 expression enhances the invasiveness of human prostate cancer cells by a protein kinase C delta-dependent mechanism. Cancer Res 2007; 67: 10859-10868.

27. Kharait S, Dhir R, Lauffenburger D, Wells A. Protein kinase $C$ delta signaling downstream of the EGF receptor mediates migration and invasiveness of prostate cancer cells. Biochem Biophys Res Commun 2006; 343: 848-856.

28. Sumitomo M, Asano T, Asakuma J, Asano T, Nanus DM, Hayakawa M. Chemosensitization of androgen-independent prostate cancer with neutral endopeptidase. Clin Cancer Res 2004; 10: 260-266.

29. Sumitomo M, Ohba M, Asakuma J, Asano T, Kuroki T, Asano T et al. Protein kinase C delta amplifies ceramide formation via mitochondrial signaling in prostate cancer cells. J Clin Invest 2002; 109: 827-836.

30. Gonzalez-Guerrico AM, Kazanietz MG. Phorbol ester-induced apoptosis in prostate cancer cells via autocrine activation of the extrinsic apoptotic cascade: a key role for protein kinase C delta. J Biol Chem 2005; 280: 38982-38991.

31. Suh J, Rabson AB. NF-kappaB activation in human prostate cancer: important mediator or epiphenomenon? J Cell Biochem 2004; 91: 100-117.

32. Nakai Y, Irie S, Sato TA. Identification of IkappaBalpha as a substrate of Fas-associated phosphatase-1. Eur J Biochem 2000; 267: 7170-7175.

33. Li L, Ittmann MM, Ayala G, Tsai MJ, Amato RJ, Wheeler TM et al. The emerging role of the PI3-K-Akt pathway in prostate cancer progression. Prostate Cancer Prostatic Dis 2005; 8: 108-118.

34. Cornford P, Evans J, Dodson A, Parsons K, Woolfenden A, Neoptolemos J et al. Protein kinase $C$ isoenzyme patterns characteristically modulated in early prostate cancer. Am J Pathol 1999; 154: 137-144.

35. Révillion F, Puech C, Rabenoelina F, Chalbos D, Peyrat JP, Freiss G. Expression of the putative tumor suppressor gene PTPN13/PTPL1 is an independent prognostic marker for overall survival in breast cancer. Int J Cancer 2009; 124: 638-643.

36. Lopez-Beltran A, Mikuz G, Luque RJ, Mazzucchelli R, Montironi R. Current practice of Gleason grading of prostate carcinoma. Virchows Arch 2006; 448: 111-118.

37. Castilla C, Congregado B, Chinchón D, Torrubia FJ, Japón MA, Sáez C. Bcl-xL is overexpressed in high-grade prostate cancer and promotes survival of $\mathrm{LNCaP}$ cells via interaction with pro-apoptotic Bak. Endocrinology 2006; 147: 4960-4967.

(c) (i) (s) $\odot$ Cell Death and Disease is an open-access journal cc) published by Nature Publishing Group. This work is licensed under the Creative Commons Attribution-NonCommercial-No Derivative Works 3.0 Unported License. To view a copy of this license, visit http://creativecommons.org/licenses/by-nc-nd/3.0/

Supplementary Information accompanies this paper on Cell Death and Disease website (http://www.nature.com/cddis) 